\title{
Fuzzy Analytic Hierarchy Process Untuk Menganalisa Faktor Pemilihan Teller Terbaik
}

\author{
Yesni Malau' ${ }^{1}$, Ulfa Maulida ${ }^{2}$ \\ Universitas Bina Sarana Informatika1, STMIK Nusa Mandiri², \\ Jl. Kamal Raya No.18, Ringroad Barat, Jakarta ${ }^{1}$, Jl. Kramat Raya No.18, Jakarta Pusat ${ }^{2}$ \\ yesni.ymu@bsi.ac.id ${ }^{1}$,ulfaamaulida@gmail.com ${ }^{2}$
}

\begin{abstract}
In an effort to provide motivation to improve the dedication and performance of the teller, the selection of the best teller is done periodically every year, some criteria that are performance appraisals are discipline, initiative, thorough, friendly, and speed of service, During this time the assessment of tellers by the Branch Manager does not yet have a method that can handle priority problems with many of these criteria so that the Branch Manager often has difficulty in choosing the best employee objectively.For the sake of work efficiency and effectiveness, we need an appropriate decision-making method with the aim to build and provide an alternative to a decision support system that is the Analytical Hierarchy Process (AHP) method,in the AHP method there is the concept of eigen vector for the priority ranking process of each criterion based on a pairwise comparison matrix, this will facilitate the process of selecting the best teller because the concept is simple, easy to understand,the computation is efficient and has the ability to measure performance and alternative decisions in a simple mathematical form,so that we will get the best teller who deserves to get the best teller (bonus) allowance and a better career path in the future. And application programs are made in order to facilitate the application of the use of the AHP method when implemented.
\end{abstract}

Keywords: SPK, AHP, Application, Teller, Fuzzy

\begin{abstract}
Abstrak
Dalam upaya memberikan motivasi untuk meningkatkan dedikasi dan kinerja teller, maka dilakukan pemilihan teller terbaik secara periodik setiap setahun sekali, beberapa kriteria yang menjadi penilaian kinerja yaitu disiplin, inisiatif, teliti, ramah, dan kecepatan pelayanan, selama ini penilaian para teller oleh Branch Manager belum memiliki metode yang dapat menangani permasalahan prioritas dengan banyaknya kriteria tersebut sehingga Branch Manager sering kesulitan dalam memilih pegawai terbaik secara objektif. Demi efisensi dan efektifitas kerja maka dibutuhkan sebuah metode pengambilan keputusan yang tepat dengan tujuan untuk membangun dan memberikan alternatif sebuah sistem pendukung keputusan yaitu metode Analytical Hierarchy Process (AHP), dalam metode AHP terdapat konsep eigen vector untuk proses perangkingan prioritas setiap kriteria berdasarkan matriks perbandingan berpasangan, hal ini akan memudahkan dalam proses pemilihan teller terbaik karena konsepnya sederhana, mudah dipahami, komputasinya efisien dan memiliki kemampuan untuk mengukur kinerja dan alternatif-alternatif keputusan dalam bentuk matematis yang sederhana, sehingga akan didapatkan teller terbaik yang layak untuk mendapatkan tunjangan teller (bonus) terbaik dan jenjang karir yang lebih baik kedepannya. Dan aplikasi program dibuat guna mempermudah dalam penggunaan metode AHP saat diimplementasikan
\end{abstract}

Kata kunci: SPK, AHP, Aplikasi, Teller, Fuzzy

\section{PENDAHULUAN}

Peranan teller dalam melayani nasabah sangat penting, bank membutuhkan teller yang handal untuk lebih produktif guna membesarkan dan memajukan perusahaan dimasa yang akan datang, Sementara masih ada 
beberapa pegawai teller yang menyepelekan konsistensi dalam pelayanan seperti dalam greeting atau ucapan salam saat bertransaksi hingga akhir transaksi karena mereka berpikir bahwa diantara nasabah yang datang adalah orang yang sama disetiap harinya. Oleh karena itu perlu dilakukan pemilihan teller terbaik guna memacu semangat karyawan dalam meningkatkan dedikasi dan kinerjanya. Kinerja karyawan cukup berpengaruh dalam keuntungan yang di dapat oleh perusahaan dan untuk memacu kinerja karyawan, maka suatu perusahaan melakukan pemilihan karyawan berprestasi pada setiap periode dengan memberikan bonus atau kenaikan gaji pada setiap karyawan yang telah terpilih[1]. Perusahaan dalam kurun waktu tertentu selalu melakukan penilaian kinerja karyawannya. Penilaian yang dilakukan setiap perusahaan mengikuti kebijakan yang berbeda-beda. Penilaian kinerja karyawan tersebut sebagai bentuk penilaian kerja nyata atas standar kualitas maupun kuantitas yang dihasilkan oleh karyawan. Penilaian prestasi kerja penting bagi setiap karyawan maupun perusahaan untuk mengambil keputusan dan menentukan kebijaksanaan selanjutnya. Kegagalan perusahaan dalam menilai kinerja karyawan dapat mengakibatkan kegagalan perusahan dalam mencapai target umum perusahaan dan dapat menurunkan motivasi karyawan dalam berprestasi[2].

Dalam manajemen pengambil keputusan tentunya dituntut untuk menghasilkan sebuah keputusan secara cepat dan tepat, guna menerapkan kebijakan yang akan dilaksanakan, penggunaan sebuah metode dalam menunjang pengambilan keputusan pun sudah banyak diterapkan, karena penggunaan metode dapat membantu manajemen dalam mengambil sebuah keputusan, selain itu penggunaan sebuah metode penunjang keputusan juga dianggap lebih memiliki nilai objektif yang tinggi dibandingkan dengan sistem manual yang rentan dengan keputusan yang bersifat subjektif, Dan salah satu metode yang paling banyak digunakan dalam manajemen pengambilan keputusan adalah metode Analytical Hierarchy Process (AHP) karena konsep metode ini dianggap sederhana, mudah dipahami, komputasinya efisien dan memiliki kemampuan untuk mengukur kinerja dan alternatif-alternatif keputusan dalam bentuk matematis yang sederhana.

Penilaian kinerja karyawan bagian Customer Service Representative (CSR) Bank Permata bertujuan untuk meningkatkan prestasi pada bagian CSR dan memberikan apresiasi untuk setiap karyawan yang telah memiliki prestasi lebih tinggi dari karyawan lain. Analytic Hierarchy Process (AHP) merupakan salah satu metode yang dapat digunakan sebagai sistem penunjang keputusan dalam menentukan penilaian kinerja karyawan [3]. Uji coba dalam sistem ini menggunakan data penilaian karyawan tahun 2016, dan hasilnya jika dibandingkan dengan penilaian dengan proses kalkulasi manual sebelumnya maka akurasi hasilnya signifikan berbeda. Hal ini membuktikan adanya ketidaktepatan dalam penilaian kinerja karyawan, 
karena dengan hasil proses kalkulasi manual tersebut benar adanya terdapat complain dari karyawan dan meningkatkan kecemburuan social antar karyawan. Dari penelitian yang disimpulkan dengan penerapan metode fuzzy AHP dalam penilaian kinerja karyawan mampu meningkatkan efektifitas proses penilaian [4]. Untuk itu perlu digunakan sebuah sistem pendukung keputusan dalam melakukan evaluasi penilaian kinerja teller dengan metode Analytical Hierarchy Process (AHP) sebagai metode dalam mendukung proses pemilihan teller terbaik, Dan untuk mendukung dan mempermudah penggunakan metode tersebut maka perlu dibangun sebuah aplikasi program dengan metode Analytical Hierarchy Process (AHP).

\section{METODOLOGI PENELITIAN}

\subsection{Tahapan Penelitian}

Berikut tahapan yang dilakukan dalam penelitian sistem pendukung keputusan pemilihan teller terbaik

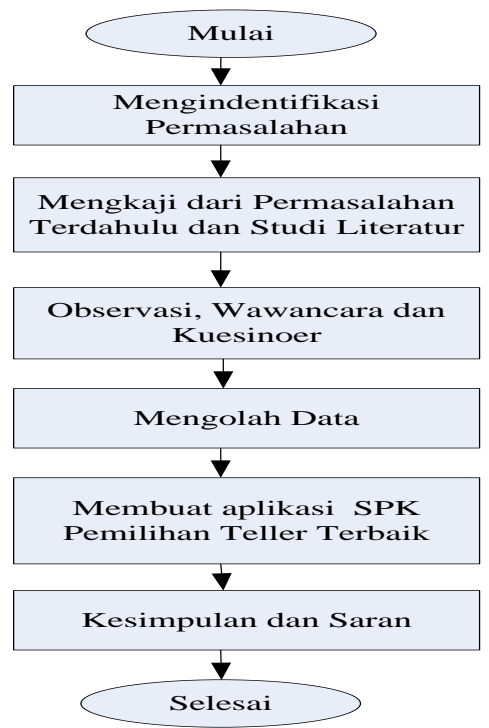

Gambar 1. Diagram Alur Proses Penelitian

Indentifikasi masalah dilakukan karena adanya permasalahan pada saat pemilihan teller terbaik yang dianggap kurang akurat dan tidak objektif, sehingga dilakukan perumusan masalah dengan mengkaji penelitian terdahulu dan studi literatur dari berbagai referensi seperti buku dan jurnal dan referensi lain yang mendukung penelitian ini, selanjutnya dilakukan observasi dan wawancara dan pembuatan kuesioner untuk mengumpulkan data yang dibutuhkan, hasil kuesioner yang telah diisi oleh para officer akan direkap, dan dilakukan penghitungan menggunakan metode Analytical Hierarki Process (AHP) dan pembuatan aplikasi SPK Pemilihan teller terbaik, kemudian menjabarkan hasil penelitian yang dilakukan dengan membuat kesimpulan serta saran. 


\subsection{Sistem Pendukung Keputusan (Decision Support System)}

Decision Support System (DSS) adalah sistem berbasis komputer yang interaktif dalam membantu pengambil keputusan dengan memanfaatkan data dan model untuk menyelesaikan masalah-masalah yang tak terstruktur. Decision Support System (DSS) dengan didukung oleh sebuah sistem informasi berbasis komputer dapat membantu seseorang meningkatkan kinerjanya dalam pengambilan keputusan [5].

\subsection{Metode Analytical Hierarki (AHP)}

Metode Analytical Hierarki (AHP) merupakan teknik pengambilan keputusan/optimasi multivariate yang digunakan dalam analisis kebijaksanaan. Pada hakikatnya AHP merupakan suatu model pengambilan keputusan yang komprehensif dengan memperhitungkan hal-hal yang bersifat kualitatif dan kuantitatif [5].

\subsection{Database}

SQL Server 2008 adalah sebuah terobosan baru dari microsoft dalam bidang database, SQL Server merupakan sebuah Database Management System (DBMS) yang dibuat oleh microsoft untuk ikut berkecimpung dalam persaingan dunia pengolahan data menyusul pendahulunya sepserti IBM dan Oracle [6].

\section{HASIL DAN PEMBAHASAN}

\subsection{Pengolahan Data Dengan Analytical Hierarchy Process (AHP)}

Untuk menentukan penelitian dan pembahasan yang dilakukan menggunakan metode Analytical Hierarchy Process (AHP). Dengan Prinsip dasar meliputi : Decomposition, Comparative Judgement, Synthesis of priority, Consistency. Setelah nilai dari responden dikonversi dan dijumlahkan keseluruhannya dan dibagi dengan banyaknya responden, maka nilai AHP kemudian dimasukkan ke dalam tabel sebagai berikut:

Tabel 1. Konversi AHP

\begin{tabular}{|l|c|c|c|c|c|}
\hline \multicolumn{5}{|c|}{ Penjumlahan Kolom Marik Berdasarkan Kriteria Utama } \\
\hline Kriteria & Disiplin & Inisiatif & Teliti & Ramah & Kecepatan P \\
\hline Disiplin & 1,00 & 2,98 & 0,44 & 0,35 & 0,37 \\
\hline lnisiatif & 0,33 & 1,00 & 0,61 & 0,27 & 0,28 \\
\hline Teliti & 2,25 & 4,60 & 1,00 & 2,41 & 2,23 \\
\hline Ramah & 2,81 & 3,64 & 0,41 & 1,00 & 1,10 \\
\hline Kecepatan P & 2,71 & 3,54 & 0,44 & 0,90 & 1,00 \\
\hline TOTAL & 9,10 & 15,76 & 2,91 & 4,94 & 4,98 \\
\hline
\end{tabular}


Selanjutnya perbandingan berpasangan antar alternatif berdasarkan kriteria "Disiplin" yang telah di nilai oleh responden dikonversi dan dijumlahkan keseluruhannya dan dibagi dengan banyaknya responden, maka nilai AHP kemudian dimasukkan ke dalam tebel berikut ini :

Tabel 2. Perbandingan alternatif berdasarkan kriteria Disiplin

\begin{tabular}{|c|c|c|c|}
\hline \multicolumn{4}{|c|}{ Penjumlahan Kolom Matuk Berdasarkan Disiplin } \\
\hline Kriteria & Teller I & Teller 2 & Teller 3 \\
\hline Teler I & 1,00 & 2,27 & 1,34 \\
\hline Teller 2 & 0,44 & 1,00 & 0,80 \\
\hline Teller 3 & 0,74 & 1,24 & 1,00 \\
\hline TOTAL & 2,18 & 4,51 & 3,14 \\
\hline
\end{tabular}

Selanjutnya kuesioner perbandingan berpasangan antar alternatif berdasarkan kriteria "Inisiatif" yang telah di nilai oleh responden dikonversi dan dijumlahkan keseluruhannya dan dibagi dengan banyaknnya responden, maka nilai AHP kemudian dimasukkan kedalam tabel berikut ini :

Tabel 3.Perbandingan alternatif berdasarkan kriteria Inisiatif

\begin{tabular}{|c|c|c|c|}
\hline \multicolumn{4}{|c|}{ Penjumlahan Kolom Matrik Berdasarkan Inisiatif } \\
\hline Kriteria & Teller 1 & Teller 2 & Teller 3 \\
\hline Teller 1 & 1,00 & 1,46 & 2,29 \\
\hline Teller 2 & 0,68 & 1,00 & 1,20 \\
\hline Teller 3 & 0,44 & 0,83 & 1,00 \\
\hline TOTAL & 2,12 & 3,30 & 4,49 \\
\hline
\end{tabular}

Selanjutnya kuesioner perbandingan berpasangan antar alternatif berdasarkan kriteria "Teliti" yang telah di nilai oleh responden dikonversi dan dijumlahkan keseluruhannya dan dibagi dengan banyaknya responden, maka nilai AHP kemudian dimasukkan kedalam tabel berikut ini :

Tabel 4. Perbandingan alternatif berdasarkan kriteria Teliti

\begin{tabular}{|l|c|c|c|}
\hline \multicolumn{4}{|c|}{ Penjumlahan Kolom Matrik Berdasarkan Teliti } \\
\hline Kriteria & Teller 1 & Teller 2 & Teller 3 \\
\hline Teller 1 & 1,00 & 2,03 & 3,48 \\
\hline Teller 2 & 0,49 & 1,00 & 1,21 \\
\hline Teller 3 & 0,29 & 0,82 & 1,00 \\
\hline TOTAL & 1,78 & 3,86 & 5,69 \\
\hline
\end{tabular}

Selanjutnya kuesioner perbandingan berpasangan antar alternatif berdasarkan kriteria "Ramah" yang telah di nilai oleh responden dikonversi 
dan dijumlahkan keseluruhannya dan dibagi dengan banyaknya responden, maka nilai AHP kemudian dimasukkan kedalam tabel berikut ini :

Tabel 5. Perbandingan alternatif berdasarkan kriteria Ramah

\begin{tabular}{|l|c|c|c|}
\hline \multicolumn{4}{|c|}{ Penjumlahan Kolco Matik Bexdazarkan Ramah } \\
\hline Kriteni1 & Teller 1 & Teller 2 & Teller 3 \\
\hline Teller 1 & 1,00 & 5,06 & 1,89 \\
\hline Teller 2 & 0,20 & 1,00 & 0,25 \\
\hline Teller 3 & 0,53 & 4,00 & 1,00 \\
\hline TOTAL & 1,72 & 10,06 & 3,14 \\
\hline
\end{tabular}

Selanjutnya kuesioner perbandingan berpasangan antar alternatif berdasarkan kriteria "Kecepatan Pelayanan" yang telah di nilai oleh responden dikonversi dan dijumlahkan keseluruhannya dan dibagi dengan banyaknya responden, maka nilai AHP kemudian dimasukkan kedalam tabel berikut ini :

Tabel 6. Perbandingan alternatif berdasarkan kriteria Kecepatan Pelayanan

\begin{tabular}{|c|c|c|c|}
\hline \multicolumn{4}{|c|}{ 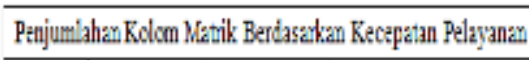 } \\
\hline Krittria & Tellet 1 & Teller 2 & Tê̈ter 3 \\
\hline Tedter 1 & 1,00 & 5,81 & 2,81 \\
\hline Teller 2 & 0,17 & 1,00 & 0,89 \\
\hline Tellet 3 & 0,35 & 1,12 & 1,00 \\
\hline TOTAL & 1,53 & 7,93 & 4,70 \\
\hline
\end{tabular}

Setelah membuat matriks perbandingan berpasangan, langkah berikutnya adalah mencari nilai rata-rata (vector eigen atau local priority) dari tiap matrik perbandingan berpasangan. Proses synthesis of priority dilakukan sebanyak jumlah matrik perbandinganyang telah dibuat. Langkah pertama dari Synthesis of priority adalah menjumlahkan nilai-nilai dari setiap kolom. Langkah kedua dari synthesis of priority adalah membuat normalisasi matrik perbandingan berpasangan dengan cara membagi nilai-nilai cell pada setiap kolom dengan total nilai dari kolom yang bersangkutan.

Tabel 7. Normalisasi berdasarkan kriteria utama

\begin{tabular}{|c|c|c|c|c|c|c|}
\hline \multicolumn{7}{|c|}{ Nonmalisasi Matrik Berdasurkan Kriknia Utema } \\
\hline Kriteria & Disipin & Fisizai & Teliti & Ramah & Keteyaran P & Rata-rea \\
\hline Disiplin & 0,11 & 0,19 & 0,15 & 0,07 & 0,07 & 0,12 \\
\hline lisizif & 0,04 & 0,06 & 0,21 & 0,06 & 0,06 & 0,08 \\
\hline Telih & 0,25 & 0,29 & 0.34 & 0.49 & 0,45 & 0,36 \\
\hline Ramah & 0,31 & 0,23 & 0,14 & 0,20 & 0,22 & 0,22 \\
\hline Kecteptan P & 0,30 & 0,22 & 0,15 & 0,18 & 0,20 & 0,21 \\
\hline \multicolumn{6}{|c|}{ Eisen Vector } & 1,00 \\
\hline
\end{tabular}


Nilai rata-rata diatas diperoleh dari penjumlahan masing-masing elemen dibagi dengan jumlah elemen. Dari vector eigen diatas terlihat bahwa :

1. Kriteria Teliti memiliki prioritas tertinggi pertama dengan nilai 0,36

2. Kriteria Ramah memiliki prioritas kedua dengan nilai 0,22

3. Kriteria Kecepatan Pelayanan memiliki prioritas ketiga dengan nilai 0,21

4. Kriteria Disiplin memiliki prioritas keempat dengan nilai 0,12

5. Kriteria Inisiatif memiliki prioritas kelima dengan nilai 0,08

Jadi untuk urutan kriteria pemilihan pegawai Teller terbaik adalah :
a. Teliti
b. Ramah
c. Kecepatan Pelayanan
d. Disiplin
e. Inisiatif

Selanjutnya menghitung vector eigen alternatif berdasarkan kriteria "Disiplin" dan membuat normalisasi matrik perbandingan berpasangan dengan cara membagi nilai-nilai sel pada setiap kolom dengan total nilai dari kolom yang bersangkutan

Tabel 8. Normalisasi berdasarkan kriteria Disiplin

\begin{tabular}{|l|c|c|c|c|}
\hline \multicolumn{5}{|c|}{ Normalisasi Matrik Berdasarkan Disiplin } \\
\hline Kriteria & Teller 1 & Teller 2 & Teller 3 & Rata-rata \\
\hline Teller 1 & 0,46 & 0,50 & 0,43 & 0,46 \\
\hline Teller 2 & 0,20 & 0,22 & 0,25 & 0,23 \\
\hline Teller 3 & 0,34 & 0,28 & 0,32 & 0,31 \\
\hline Eiggen Vector & 1,00 \\
\hline
\end{tabular}

Selanjutnya menghitung vector eigen alternatif berdasarkan kriteria "Inisiatif" dan membuat normalisasi matrik perbandingan berpasangan dengan cara membagi nilai-nilai sel pada setiap kolom dengan total nilai dari kolom yang bersangkutan.

Tabel 9. Normalisasi berdasarkan kriteria Inisiatif

\begin{tabular}{|l|c|c|c|c|}
\hline \multicolumn{5}{|c|}{ Nomalisasi Netrik Berdasarka misianif } \\
\hline Kritenia & Teller 1 & Teller 2 & Teller 3 & Rata-ata \\
\hline Teller 1 & 0,47 & 0,44 & 0,51 & 0,48 \\
\hline Teller 2 & 0,32 & 0,30 & 0,27 & 0,30 \\
\hline Telller 3 & 0,21 & 0,25 & 0,22 & 0,23 \\
\hline Eigen Vector & & 1,00 \\
\hline
\end{tabular}

Selanjutnya menghitung vector eigen alternatif berdasarkan kriteria "Teliti" dan membuat normalisasi matrik perbandingan berpasangan dengan cara 
membagi nilai-nilai sel pada setiap kolom dengan total nilai dari kolom yang bersangkutan.

Tabel 10. Normalisasi berdasarkan kriteria Teliti

\begin{tabular}{|l|c|c|c|c|}
\hline \multicolumn{5}{|c|}{ Nomalisasi Natrik Berdasarkan Teliti } \\
\hline Kiteria & Teller 1 & Teller 2 & Teller 3 & Rata-Iata \\
\hline Teller 1 & 0,56 & 0,53 & 0,01 & 0,57 \\
\hline Teller 2 & 0,28 & 0,26 & 0,21 & 0,25 \\
\hline Teller 3 & 0,16 & 0,21 & 0,18 & 0,18 \\
\hline \multicolumn{4}{|l|}{ Eigen Vector } & 1,00 \\
\hline
\end{tabular}

Selanjutnya menghitung vector eigen alternatif berdasarkan kriteria "Ramah" dan membuat normalisasi matrik perbandingan berpasangan dengan cara membagi nilai-nilai sel pada setiap kolom dengan total nilai dari kolom yang bersangkutan.

Tabel 11. Normalisasi berdasarkan kriteria Ramah

\begin{tabular}{|l|c|c|c|c|}
\hline \multicolumn{5}{|c|}{ Nomalisasi Natrik Berdasarkan Ramah } \\
\hline Kriteria & Teller 1 & Teller 2 & Teller 3 & Rata-rata \\
\hline Teller 1 & 0,58 & 0,50 & 0,60 & 0,56 \\
\hline Teller 2 & 0,11 & 0,10 & 0,08 & 0,10 \\
\hline Teller 3 & 0,31 & 0,40 & 0,32 & 0,34 \\
\hline \multicolumn{4}{|l|}{ Eigen Vector } & 1,00 \\
\hline
\end{tabular}

Selanjutnya menghitung vector eigen alternatif berdasarkan kriteria "Kecepatan Pelayanan" dan membuat normalisasi matrik perbandingan berpasangan dengan cara membagi nilai-nilai sel pada setiap kolom dengan total nilai dari kolom yang bersangkutan

Tabel 12. Normalisasi berdasarkan kriteria Kecepatan Pelayanan

\begin{tabular}{|l|c|c|c|c|}
\hline \multicolumn{5}{|c|}{ Nomalisasi Natik Berdasurkan Kecepatan Pelayanan } \\
\hline Rriteria & Teller 1 & Teller 2 & Teller 3 & Rata-rata \\
\hline Teller 1 & 0,60 & 0,73 & 0,60 & 0,66 \\
\hline Teller 2 & 0,11 & 0,13 & 0,19 & 0,14 \\
\hline Teller 3 & 0,23 & 0,14 & 0,21 & 0,20 \\
\hline Ejgen Vector & 1,00 \\
\hline
\end{tabular}


Dalam pembuatan laporan, seberapa baik konsistensi yang ada penting untuk diketahui bahwa kita tidak menginginkan keputusan berdasarkan pertimbangan dengan konsistensi yang rendah. Hal-hal yang dilakukan dalam langkah ini yaitu :

a. Mengalikan setiap nilai pada kolom pertama dengan prioritas relative elemen pertama, nilai pada kolom kedua dengan prioritas relatif kedua dan seterusnya

b. Jumlahkan setiap baris

c. Hasil dari penjumlahan baris dibagi dengan elemen prioritas elemen relaif yang bersangkutan

d. Jumlahkan hasil bagi diatas dengan banyaknya elemen yang ada, hasilnya disebut $\lambda$ maksimal

e. Hitung Consistency Index (CI) dengan rumus : $\mathrm{CI}=(\lambda$ maks- $n) /(n-1)$

f. Hitung Rasio Konsistensi / Consistency Ratio (CR) dengan rumus : $\mathrm{CR}=$ $\mathrm{CI} / \mathrm{I}$

1) Konsistensi Level 1 Berdasarkan Kriteria Utama

$$
\begin{aligned}
& \left(\begin{array}{ccccc}
1 & 2,98 & 0,44 & 0,35 & 0,37 \\
0,33 & 1 & 0,61 & 0,27 & 0,28 \\
2,25 & 4,6 & 1 & 2,41 & 2,23 \\
2,81 & 3,64 & 0,41 & 1 & 1,1 \\
2,71 & 3,54 & 0,44 & 0,9 & 1
\end{array}\right) *\left(\begin{array}{l}
0,12 \\
0,08 \\
0,36 \\
0,22 \\
0,21
\end{array}\right) \\
= & \left(\begin{array}{ccccc}
0,12 & 0,2384 & 0,1584 & 0,077 & 0,0777 \\
0,0396 & 0,08 & 0,2196 & 0,0594 & 0,0588 \\
0,27 & 0,08 & 0,36 & 0,5302 & 0,4683 \\
0,3372 & 0,0328 & 0,1476 & 0,22 & 0,231 \\
0,3252 & 0,0352 & 0,324 & 0,198 & 0,21
\end{array}\right)=\left(\begin{array}{l}
0,6715 \\
0,4574 \\
1,7085 \\
0,9686 \\
1,0924
\end{array}\right) /\left(\begin{array}{l}
0,12 \\
0,08 \\
0,36 \\
0,22 \\
0,21
\end{array}\right) \\
= & \left(\begin{array}{c}
5,55583 \\
5,7175 \\
4,74583 \\
4,40273 \\
5,2019
\end{array}\right)
\end{aligned}
$$

$\lambda=(5,59583+5,7175+4,74583+4,40273+5,2019) / 5=5,13276$

$\mathrm{CI}=(5,13276-5) /(5-1)=0,03319$

$\mathrm{CR}=0,03319 / 1.12=0,02963$

Jadi karena nilai CR < 0,1 (10\%) maka "dapat diterima", artinya : Matriks perbandingan berpasangan level 1 berdasarkan kriteria utama telah diisi dengan pertimbangan - pertimbangan yang konsisten dan eigen vector yang dihasilkan dapat diandalkan.

2) Konsistensi Level 2 Berdasarkan Kriteria Disiplin

$$
\begin{aligned}
& \left(\begin{array}{ccc}
1 & 2,27 & 1,34 \\
0,44 & 1 & 0,8 \\
0,74 & 1,24 & 1
\end{array}\right) *\left(\begin{array}{l}
0,46 \\
0,23 \\
0,31
\end{array}\right)=\left(\begin{array}{ccc}
0,46 & 0,5221 & 0,4154 \\
0,2024 & 0,23 & 0,248 \\
0,3404 & 0,2852 & 0,31
\end{array}\right)=\left(\begin{array}{l}
1,3975 \\
0,6804 \\
0,9356
\end{array}\right) /\left(\begin{array}{l}
0,46 \\
0,23 \\
0,31
\end{array}\right) \\
& =\left(\begin{array}{l}
3,038043 \\
2,958261 \\
3,018065
\end{array}\right)
\end{aligned}
$$

$\lambda=(3,038043+2,958261+43,018065) / 3=3,00479$

$\mathrm{CI}=(3,00479-3) /(3-1)=0,002395$

$\mathrm{CR}=0,002395 / 0.58=0,004129$ 
Jadi karena nilai CR < 0,1 (10\%) maka "dapat diterima", artinya : Matriks perbandingan berpasangan level 2 berdasarkan kriteria disiplin telah diisi dengan pertimbangan - pertimbangan yang konsisten dan eigen vector yang dihasilkan dapat diandalkan.

3) Konsistensi Level 2 Berdasarkan Kriteria Inisiatif

$$
\begin{aligned}
& \left(\begin{array}{ccc}
1 & 1,46 & 2,29 \\
0,68 & 1 & 1,2 \\
0,44 & 0,83 & 1
\end{array}\right) *\left(\begin{array}{l}
0,48 \\
0,3 \\
0,23
\end{array}\right)=\left(\begin{array}{ccc}
0,48 & 0,438 & 0,5267 \\
0,3264 & 0,3 & 0,276 \\
0,2112 & 0,249 & 0,23
\end{array}\right)=\left(\begin{array}{l}
1,4447 \\
0,9024 \\
0,6902
\end{array}\right) /\left(\begin{array}{l}
0,48 \\
0,3 \\
0,23
\end{array}\right) \\
& =\left(\begin{array}{l}
3,00622 \\
0,00311 \\
0,005362
\end{array}\right)
\end{aligned}
$$

$\lambda=(3,00622+0,00311+0,005362) / 3=3,00622$

$\mathrm{CI}=(3,00622-3) /(3-1)=0,00311$

$\mathrm{CR}=0,00311 / 0.58=0,005362$

Jadi karena nilai CR < 0,1 (10\%) maka "dapat diterima", artinya : Matriks perbandingan berpasangan level 2 berdasarkan kriteria inisiatif telah diisi dengan pertimbangan - pertimbangan yang konsisten dan eigen vector yang dihasilkan dapat diandalkan.

4) Konsistensi Level 2 Berdasarkan Kriteria Teliti

$$
\begin{aligned}
\left(\begin{array}{ccc}
1 & 2,03 & 3,48 \\
0,49 & 1 & 1,21 \\
0,29 & 0,82 & 1
\end{array}\right) *\left(\begin{array}{l}
0,57 \\
0,25 \\
0,18
\end{array}\right)=\left(\begin{array}{ccc}
0,57 & 0,5075 & 0,6264 \\
0,2793 & 0,25 & 0,2178 \\
0,1653 & 0,205 & 0,18
\end{array}\right)=\left(\begin{array}{l}
1,7039 \\
0,7471 \\
0,5503
\end{array}\right) /\left(\begin{array}{l}
0,57 \\
0,25 \\
0,18
\end{array}\right) \\
=\left(\begin{array}{c}
2,989298 \\
2,9884 \\
3,057222
\end{array}\right)
\end{aligned}
$$

$\lambda=(2,989298+2,9884+3,05722) / 3=3,01164$

$\mathrm{CI}=(3,01164-3) /(3-1)=0,00582$

$\mathrm{CR}=0,00582 / 0.58=0,010035$

Jadi karena nilai CR < 0,1 (10\%) maka "dapat diterima", artinya : Matriks perbandingan berpasangan level 2 berdasarkan kriteria teliti telah diisi dengan pertimbangan-pertimbangan yang konsisten dan eigen vector yang dihasilkan dapat diandalkan.

5) Konsistensi Level 2 Berdasarkan Kriteria Ramah

$$
\begin{aligned}
\left(\begin{array}{ccc}
1 & 5,06 & 1,89 \\
0,2 & 1 & 0,25 \\
0,53 & 4 & 1
\end{array}\right) *\left(\begin{array}{c}
0,56 \\
0,1 \\
0,34
\end{array}\right)=\left(\begin{array}{ccc}
0,56 & 0,506 & 0,6426 \\
0,112 & 0,1 & 0,085 \\
0,2968 & 0,4 & 0,34
\end{array}\right)=\left(\begin{array}{c}
1,7086 \\
0,297 \\
0,0368
\end{array}\right) /\left(\begin{array}{c}
0,56 \\
0,1 \\
0,34
\end{array}\right) \\
=\left(\begin{array}{c}
3,051071 \\
2,97 \\
3,049412
\end{array}\right)
\end{aligned}
$$


$\lambda=(3,051071+2,97+3,049412) / 3=3,100658$

$\mathrm{CI}=(3,100658-3) /(3-1)=0,050329$

$\mathrm{CR}=0,050329 / 0.58=0,086774$

Jadi karena nilai CR <0,1 (10\%) maka "dapat diterima", artinya :

Matriks perbandingan berpasangan level 2 berdasarkan kriteria ramah telah diisi dengan pertimbangan - pertimbangan yang konsisten dan eigen vector yang dihasilkan dapat diandalkan.

6) Konsistensi Level 2 Berdasarkan Kriteria Kecepatan Pelayanan

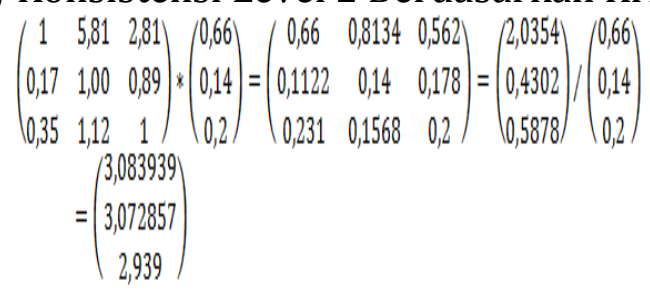

$\lambda=(3,083939+3,072857+2,939) / 3=3,031932$

$\mathrm{CI}=(3,031932-3) /(3-1)=0,015966$

$\mathrm{CR}=0,015966 / 0.58=0,027528$

Jadi karena nilai CR < 0,1 (10\%) maka "dapat diterima", artinya : Matriks perbandingan berpasangan level 2 berdasarkan kriteria kecepatan pelayanan telah diisi dengan pertimbangan - pertimbangan yang konsisten dan eigen vector yang dihasilkan dapat diandalkan.

Setelah melakukan proses pengukuran konsistensi kegiatan selanjutnya adalah melakukan sintesa global untuk pengambilan keputusannya. Prosedurnya adalah sebagai berikut :

1. Mengalikan gabungan eigen vector pada level 1(level kriteria utama) dengan eigen vector pada level 2 (level alternatif) dan hasil operasi perkalian tersebut selanjutnya disebut sebagai "Eigen Vector Keputusan".

2. Keputusan yang diambil adalah keputusan yang mempunyainilai yang paling benar

$$
\left(\begin{array}{ccccc}
0,46 & 0,48 & 0,57 & 0,56 & 0,66 \\
0,23 & 0,3 & 0,25 & 0,1 & 0,11 \\
0,31 & 0,23 & 0,18 & 0,34 & 0,23
\end{array}\right) *\left(\begin{array}{l}
0,12 \\
0,08 \\
0,36 \\
0,22 \\
0,21
\end{array}\right)=\left(\begin{array}{l}
0,5055 \\
0,2082 \\
0,2725
\end{array}\right)
$$

Dari vector eigen keputusan terlihat bahwa :

1. Teller 1 memiliki bobot prioritas tertinggi yaitu 0.5055

2. Teller 3 memiliki bobot prioritas kedua yaitu 0.2725

3. Teller 2 memiliki bobot prioritas tertinggi yaitu 0.2082 


\subsection{Rasio Konsistensi Hierarki (CRH)}

\section{$\mathrm{CRH}=\mathrm{CIH} / \mathrm{RIH}$}

Jika digambarkan dalam bentuk grafik maka dapat dilihat jumlah presentasenya sebagai berikut :

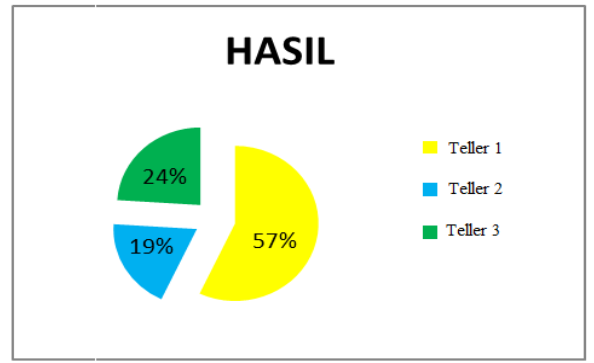

Gambar 2. Presentase Eigen Vector Keputusan

Berdasarkan eigen vector keputusan, maka didapatkan hasil dari perhitungan dengan metode AHP, Teller 1 sebagai Teller Terbaik. Perhitungan terakhir adalah melakukan pengujian Rasio Konsistensi Hierarki ( CRH), Pengujian Rasio Hierarki dapat dilakukan dengan rumus :

$\mathrm{CRH}=\mathrm{CIH} / \mathrm{RIH}$

Tabel 13. Hasil Rasio Konsistensi (CRH)

\begin{tabular}{|c|c|c|c|c|c|c|c|c|}
\hline $\mathrm{CIE}-$ & Claeril: & + & 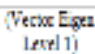 & & & & & (Cllerel:) \\
\hline & alsisile & + & 1013 & 0.68 & 0.26 & 032 & 0.31 & 06004 \\
\hline & & & & & & & & 2,02211 \\
\hline & & & & & & & & 2,02582 \\
\hline & & & & & & & & 8,01175 \\
\hline & & & & & & & & 2,01597 \\
\hline & & & & & & & & \\
\hline- & $0,033.9$ & + & 0,002574 & $0,0,0)$ & 0,020 & 0,0008 & $0,033: 5$ & \\
\hline & & & & & & & & \\
\hline$=$ & alsisis & + & oferstso & & & & & \\
\hline & & & & & & & & \\
\hline & 0.6 & & & & & & & \\
\hline
\end{tabular}

Dimana :

Tabel 14. Hasil Rasio Konsistensi (CRH)

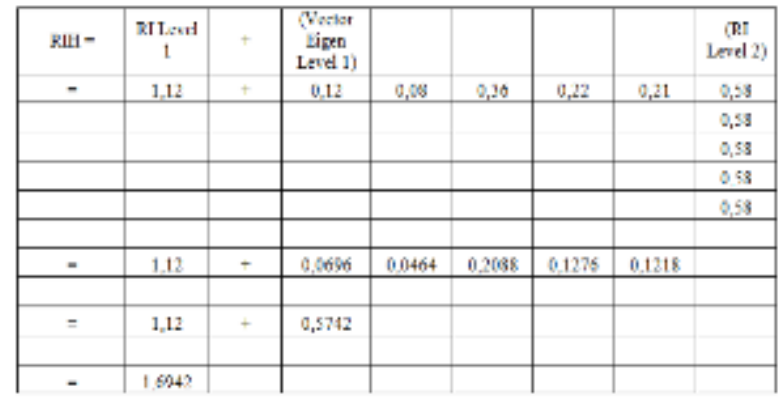

$\mathrm{CRH}=0,0417586 / 1,6942=0,02464798$ 
Dari perhitungan diatas diperoleh nilai CRH kurang dari 0.1 atau kurang dari $10 \%$ maka hirarki secara keseluruhan bersifat konsisten, sehingga kesimpulan yang diperoleh dapat diterima, artinya keputusan yang ditetapkan dapat diandalkan. Dari pernyataan tersebut dapat disimpulkan bahwa adanya pengaruh terhadap nilai dan kinerja para teller sebagai tolak ukur untuk mendapatkan teller yang terbaik dan juga sebagai penilaian terhadap bonus serta promosi yang akan didapatkan oleh teller tersebut.

\subsection{Rancangan Tabel Basis Data}

Berikut ini adalah desain model database yang dibuat dalam membangun aplikasi sistem pendukung keputusan pemilihan teller terbaik dengan menggunakan metode Analytical Hierarchy Process (AHP).

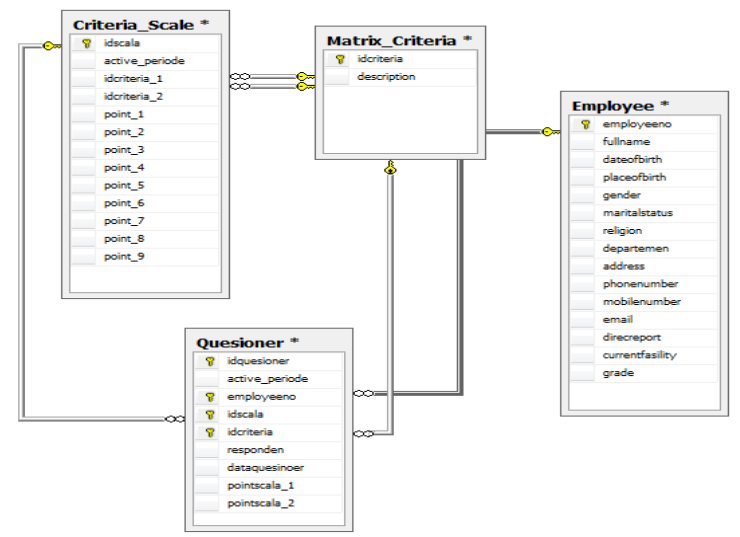

Gambar 3. Model Database

Berikut beberapa tampilan sistem informasi seperti yang ditunjukkan pada gambar berikut:

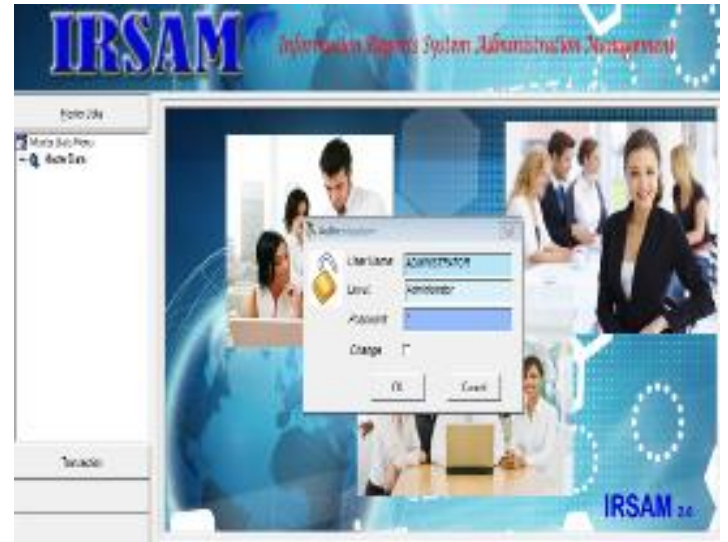

Gambar 4. Halaman Login

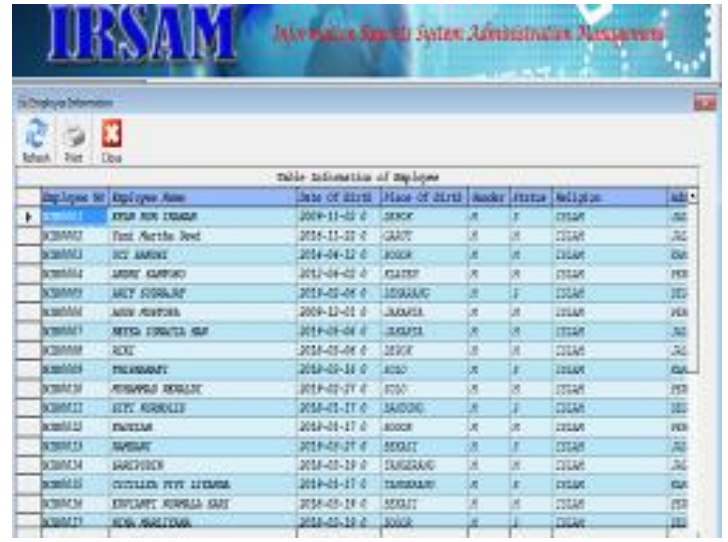

Gambar 5. Halaman Karyawan 


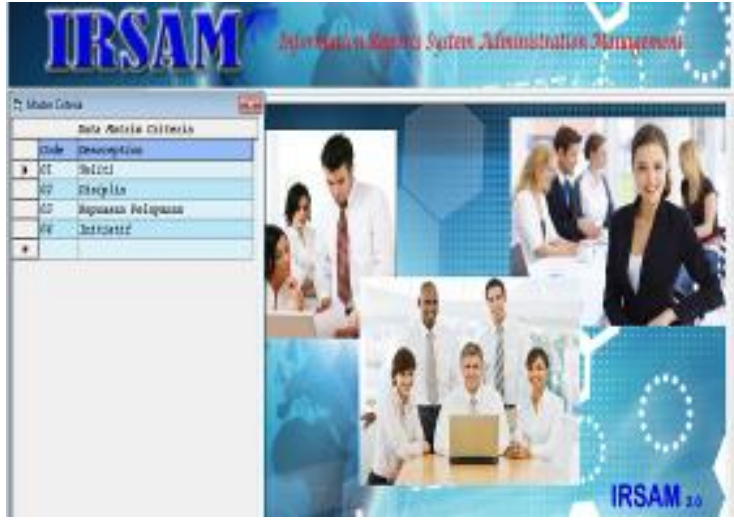

Gambar 6. Halaman Matriks

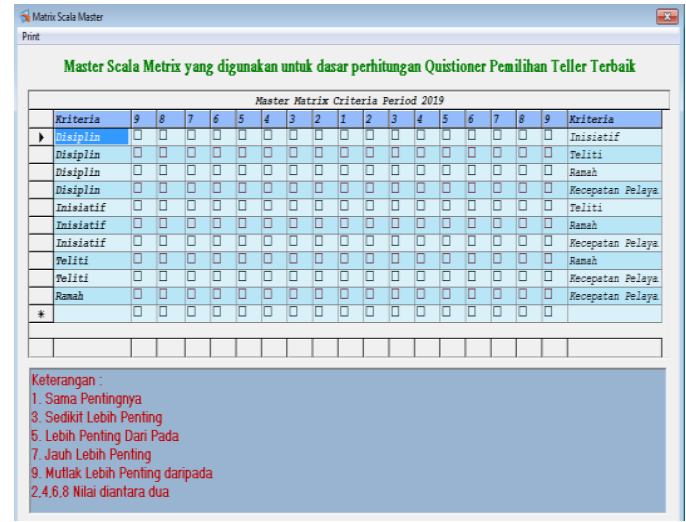

Gambar 7. Halaman Matriks Scala

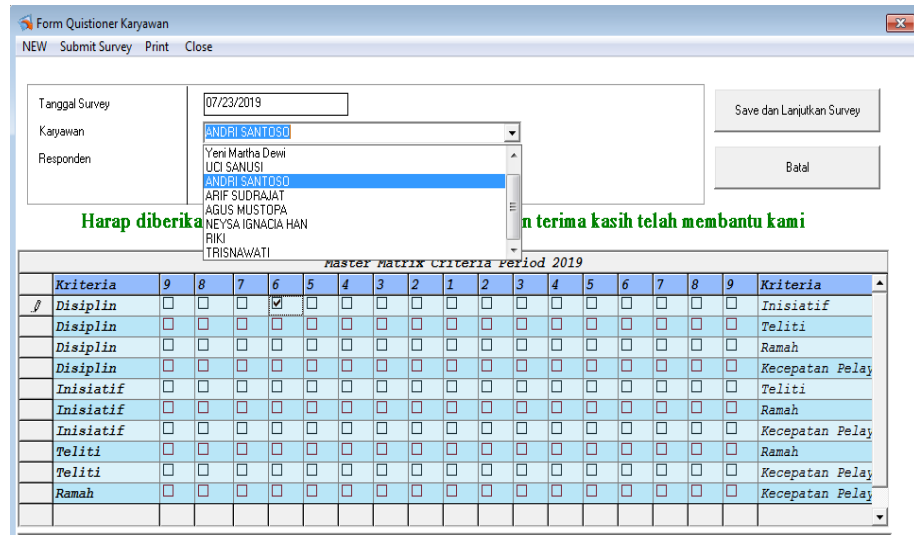

Gambar 8. Tampilan Halaman Quesioner Penilaian

\section{SIMPULAN}

Dari uraian pemilihan teller terbaik dengan meggunakan metode Analytical Hierraki Process (AHP) dapat diambil kesimpulan bahwa aplikasi sistem pendukung keputusan yang dibangun dapat membantu, mempermudah, dan mempercepat para manager atau HRD menentukan pegawai teller terbaik, tingkat keakuratan dalam menentukan pegawai teller terbaik dengan menggunakan metode AHP ini dapat dinilai dari Consistency Ratio Hierarchy/ CRH $<10 \%$ maka hasil perhitungan dapat dinyatakan benar,dalam penelitian ini perhitungan Consistency Ratio Hierarchy/ CRH adalah 0,024 atau 2,4\% itu artinya nilai dapat diterima dan hasil perhitungan dinyatakan benar, Berdasarkan vector eigen keputusan, didapatkan hasil sebagai berikut : (1) Teller 1 memilki nilai yang tertinggi yaitu 0,560. (2).Teller 3 memiliki nilai kedua tertinggi yaitu 0,2435, (3) Teller 2 memiliki nilai terendah yaitu 0,1867, Sehingga dapat disimpulkan pegawai Teller terbaik Teller 1. 
Jurnal Sains Komputer \& Informatika (J-SAKTI)

Volume 3 Nomor 2 September 2019, pp. 212-226

ISSN:2548-9771/EISSN:2549-7200

http://tunasbangsa.ac.id/ejurnal/index.php/jsakti

\section{DAFTAR PUSTAKA}

[1] Safitri, K., Waruwu, F. T., \& Mesran. (2017). Berprestasi Dengan Menggunakan Metode Analytical Analytical Hierarchy Process ( Studi Kasus: PT . Capella Dinamik Nusantara Takengon ). Issn 2548-8368, 1(1), 17-21.

[2] Umar, R., Fadlil, A., \& Yuminah. (2018). khazanah informatika Sistem Pendukung Keputusan dengan Metode AHP untuk Penilaian Kompetensi Soft Skill Karyawan, 27-34.

[3] Pernadi, D., Hanafi, A., \& Dkk. (2015). Implementasi Analytical Hierarchy Process (AHP) untuk Penilaian Kinerja pada Bagian Customer Service Representative (CSR) di PT. Bank Permata Tbk, 14, 31-42.

[4] Setiyaningsih, W., \& Prasetyo, A. Y. E. (2018). Penerapan Fuzzy AHP Untuk Peningkatan Ketepatan dan Efektivitas Kinerja Karyawan 1.

[5] Pratiwi, H. (2016). Buku Ajar Sistem Pendukung Keputusan (1st ed.). Yogyakarta: deepublish.

[6] Komputer, Wahana. (2010). SQL Server 2008 Express. Yogyakarta : Andi. 